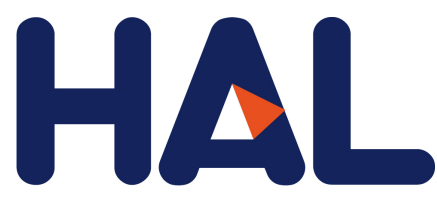

archives-ouvertes

\title{
Invited review Block of voltage-gated calcium channels by peptide toxins
}

\author{
Emmanuel Bourinet, Gerald Zamponi
}

\section{To cite this version:}

Emmanuel Bourinet, Gerald Zamponi. Invited review Block of voltage-gated calcium channels by peptide toxins. Neuropharmacology, Elsevier, 2016, 10.1016/j.neuropharm.2016.10.016 . hal-02356298

\section{HAL Id: hal-02356298 \\ https://hal.archives-ouvertes.fr/hal-02356298}

Submitted on 8 Nov 2019

HAL is a multi-disciplinary open access archive for the deposit and dissemination of scientific research documents, whether they are published or not. The documents may come from teaching and research institutions in France or abroad, or from public or private research centers.
L'archive ouverte pluridisciplinaire HAL, est destinée au dépôt et à la diffusion de documents scientifiques de niveau recherche, publiés ou non, émanant des établissements d'enseignement et de recherche français ou étrangers, des laboratoires publics ou privés. 
Invited review

\title{
Block of voltage-gated calcium channels by peptide toxins
}

\author{
Emmanuel Bourinet ${ }^{a}$, Gerald W. Zamponi ${ }^{\text {b, * }}$ \\ a Institute for Functional Genomics, CNRS UMR5203, INSERM U1191, University of Montpellier, LABEX ICST, Montpellier, France \\ ${ }^{\mathrm{b}}$ Department of Physiology and Pharmacology, Hotchkiss Brain Institute and Alberta Children's Hospital Research Institute, Cumming School of Medicine, \\ University of Calgary, Calgary, Canada
}

\section{A R T I C L E I N F O}

\section{Article history:}

Received 8 September 2016

Received in revised form

14 October 2016

Accepted 15 October 2016

Available online $\mathrm{xxx}$

\section{Keywords:}

Calcium channels

Conotoxin

Agatoxin

Protoxin

Spiders

Venom

Pain

\begin{abstract}
A B S T R A C T
Venoms from various predatory species, such as fish hunting molluscs scorpions, snakes and arachnids contain a large spectrum of toxins that include blockers of voltage-gated calcium channels. These peptide blockers act by two principal manners - physical occlusion of the pore and prevention of activation gating. Many of the calcium channel-blocking peptides have evolved to tightly occupy their binding pocket on the principal pore forming subunit of the channel, often rendering block poorly reversible. Moreover, several of the best characterized blocking peptides have developed a high degree of channel subtype selectivity. Here we give an overview of different types of calcium channel-blocking toxins, their mechanism of action, channel subtype specificity, and potential use as therapeutic agents.
\end{abstract}

๑) 2016 Elsevier Ltd. All rights reserved.

\section{Contents}

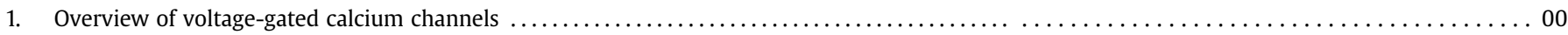

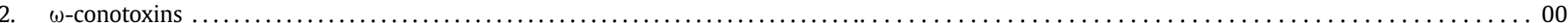

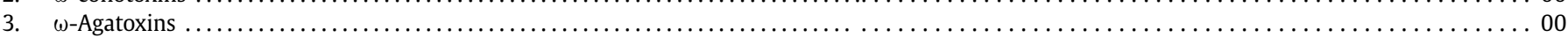

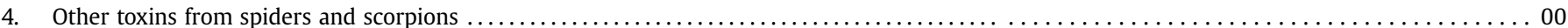

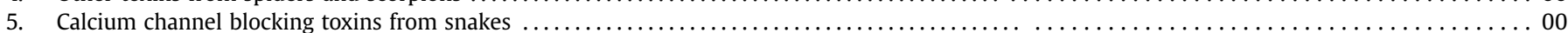

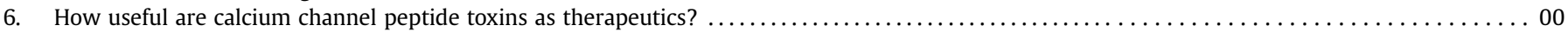

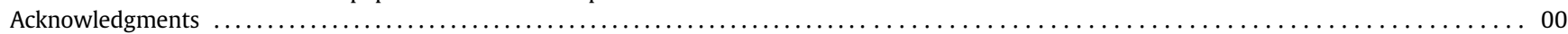

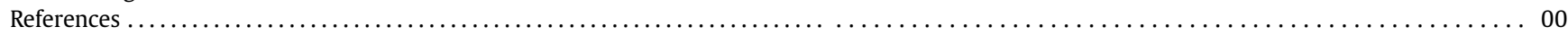

\section{Overview of voltage-gated calcium channels}

Voltage-gated calcium channels are the major source of depolarization-evoked calcium entry into excitable cells of brain, heart, and muscle (Zamponi et al., 2015). This in turn supports many critical physiological functions that range from muscle contraction, to the release of neurotransmitters and calciumdependent gene transcription, among many others. The mammalian genome encodes as many as ten different genes that lead to

\footnotetext{
* Corresponding author.

E-mail address: zamponi@ucalgary.ca (G.W. Zamponi).
}

different types of Cav subunits, the principal pore forming subunit that forms the core of the calcium permeable ion channel (Simms and Zamponi, 2014). They have been grouped into three major classes (Cav1, Cav2 and Cav3) which in turn correspond to different types of calcium currents that have been identified in native tissues (for review, see Simms and Zamponi, 2014). The Cav1 family encodes four different types of L-type channels. Among the Cav2 family, Cav2.1, Cav2.2 and Cav2.3 correspond, respectively, to P/Qtype, N-type and R-type currents. The Cav3 family represents three different types of T-type calcium channels (also known as low-voltage activated channels due to their hyperpolarized voltage range of activation) (Catterall et al., 2005). Members of the Cav3 family are thought to be monomers whereas Cav1 and Cav2 
channels are multimeric complexes that also include a cytoplasmic $\operatorname{Cav} \beta$ and an extracellular Cav $\alpha 2 \delta$ subunit (Simms and Zamponi, 2014; Catterall et al., 2005). These ancillary subunits serve primarily to regulate calcium channel trafficking and function, but have also been shown to alter the pharmacological characteristics of the channels (Dolphin, 2016). All Cav subunits share a common transmembrane topology of four homologous transmembrane domains that each contain six membrane spanning helices plus a reentrant p-loop motif that forms the pore of the channel and imparts calcium selectivity (Catterall et al., 2005). The fourth transmembrane helix in each domain contains a positively charged amino acid residue in every third position and forms the voltage sensor of the channel (Catterall, 2010). The major domains are connected by large cytoplasmic regions, in addition to being flanked by intracellular $\mathrm{N}$ - and C-terminal regions. The domain I-II linker is the locus for $\operatorname{Cav} \beta$ subunit interactions (Pragnell et al., 1994). The recent breakthrough resolution of the Cav1.1 channel structure at a nearly atomic level brings us a step closer to the understanding of the interface between the Cav subunit and ancillary subunits (Wu et al., 2015, 2016). Notably these studies revealed that Cav $\alpha 2 \delta$ has a docking site formed by extracellular segments of domains I, II, and III, all organized with other extracellular loops into a dome structure above the selectivity filter. Whether this organization is common to other Cav subtypes remains to be determined.

The Cav subunit is the target for pharmacological agents that block (and in some cases enhance) calcium channel activity (Zamponi et al., 2015). This is relevant in the context of therapeutics, as calcium channel inhibitors have been used to treat disorders such as hypertension, pain and epilepsy (for review, see Khosravani and Zamponi, 2006; Waxman and Zamponi, 2014; Bourinet et al., 2014; Zamponi et al., 2015; Zamponi, 2016). Calcium channel blockers include small inorganic ions such as cadmium which act by occluding the permeation pathway (Lansman et al., 1986), small organic molecules such as dihydropyridines which have been used as a tool to identify native L-type calcium currents (Randall and Tsien, 1995), and larger peptide-based toxins that are isolated from a wide variety of venomous animal species. Here, we provide an overview of different peptide toxins that act on various members of the calcium channel superfamily, and touch on their therapeutic potential.

\section{2. $\omega$-conotoxins}

The family of $\omega$-conotoxins is derived from the venoms of a variety of different marine molluscs that use their venom to hunt fish. They are typically between twenty and thirty amino acids in size and display a rigid backbone structure that is spatially constrained by the formation of disulfide bonds formed between six conserved cysteine residues (Olivera et al., 1986, 1991; Lewis et al., 2012). Blocking affinity and channel subtype selectivity vary with amino acid sequence in the various loops between the cysteine bonds. In general, $\omega$-conotoxins act by physically occluding the pore of the channel, thus preventing calcium influx. In many cases, binding is very tight, leading to slow dissociation rates and hence poorly reversible block (for example, Mintz et al., 1992; Boland et al., 1994; Ellinor et al., 1994).

One of the defining characteristics of Cav2.2 (N-type) calcium channels is their inhibition by $\omega$-conotoxin GVIA, a 27 amino acid peptide isolated from the fish hunting mollusc Conus geographus (Olivera et al., 1994; McCleskey et al., 1987). GVIA block is exquisitely selective for Cav2.2 channels and virtually irreversible (Boland et al., 1994; McDonough et al., 2002), however, strong membrane hyperpolarization has been shown to accelerate the dissociation of this peptide from the channel (Stocker et al., 1997;
Feng et al., 2003). Structure-function analysis based on chimeric calcium channel constructs has revealed that GVIA interacts with the outer vestibule of the pore comprised of the extracellular domain III S5-S6 (p-loop) region (Ellinor et al., 1994). Moreover, mutations in this region (especially a Glycine residue at position 1326) have been shown to affect not only the blocking rate constant, but also to have the capability to render the block reversible (Feng et al., 2001). These data fit with a structural homology model of Cav2.2 based on the structure of bacterial sodium channels (Lewis et al., 2012). This picture is likely to be refined in light of the recent structural data of the Cav1.1 channel in complex with a Cav $\alpha 2 \delta$ subunit that is docked near the top of the channel pore ( $\mathrm{Wu}$ et al., 2016). Such structural information may offer some mechanistic insights into why the $\operatorname{Cav} \alpha 2 \delta$ subunit affects blocking and unblocking rate constants for certain types of $\omega$-conotoxins (Mould et al., 2004). The venom of Conus geographus also contains other related $\omega$-conotoxins, such as GVIB, GVIC, GVIIA, and GVIIA, however they are not as well characterized at the electrophysiological level as GVIA (Olivera et al., 1994).

A number of calcium channel blocking peptides have been isolated from the venom of Conus magus, another fish hunting snail. This includes $\omega$-conotoxins MVIIA, MVIIB, MVIIC, and MVIID (Hillyard, 1992; Olivera et al., 1994), which for the most part preferentially target Cav2.2 channels (Olivera et al., 1985; Monje et al., 1993; Fox, 1995). However, MVIIC also blocks Cav2.1 calcium channels and its blocking effects are reversible (Woppmann et al., 1994; Grantham et al., 1994), underscoring the point that small changes in amino acid composition between MVIIA and MVIIC are sufficient to alter channel subtype selectivity. The mode of action of these peptides is similar to that of GIVA, and they compete for a common interaction site on the channel (Olivera et al., 1994), although subtle differences in the way these toxins interact with the channel have been suggested (Woppmann et al., 1994).

MVIIA has received particular attention, as this peptide can be synthesized such that it retains its native conformation (Xiao and Bennett, 1995). This has allowed the exploration of this peptide as a therapeutic agent for pain, based on the underlying principle that the Cav2.2 channel plays a major role in the transmission of pain signals in the spinal dorsal horn (Bourinet et al., 2014). Intrathecal delivery of MVIIA (a.k.a. ziconotide or Prialt) mediates analgesic effects in both animals and humans. However, although Prialt is approved for treating intractable cancer pain in humans it has a narrow therapeutic window and the potential for causing severe CNS side effects (Antanassoff et al., 2000; Penn and Paice, 2000; Miljanich, 2004; Staats et al., 2004; Thompson et al., 2006; Wallace et al., 2006; Ver et al., 2008). The toxicity of MVIIA has recently been attributed to a methionine residue at position 12 of the toxin molecule, which is known to dock to a hydrophobic binding pocket comprised of residues I300, F302, L305 of the Cav2.2 subunit (Wang et al., 2016).

A number of additional $\omega$-conotoxins have been identified in the venoms of Conus fulman and Conus catus and shown to mediate potent inhibition of Cav2.2 channels and to exhibit analgesic effects. This includes $\omega$-conotoxins FVIA (a reversible N-type channel blocker; Lee et al., 2010), as well as CVIB (Motin et al., 2007), CVID (Lewis et al., 2000; Scott et al., 2002; Adams et al., 2003), CVIE and CVIF (Berecki et al., 2010). Interestingly, CVID and CVIE (but not CVIF) mediate analgesia in mice even after systemic administration (Sadeghi et al., 2013). Of further note, CVID has been advanced to human clinical trials where a larger therapeutic window was observed compared with Prialt (Schroeder et al., 2006), however, this peptide did to our knowledge not advance beyond phase II. Nonetheless, the larger therapeutic window has been attributed to the fact that CVID shows greater selectivity for Cav2.2 channels over Cav2.1. 
The $\omega$-conotoxins SIA, SVIA and SVIB have been isolated from Conus striatus venom. Although they are pore blockers, it has been suggested that their sites of action are distinct from those of GVIA (Ramilo et al., 1992). Moreover, similar to MVIIC, SVIB reversibly blocks Cav2.2 and Cav2.1 channels (Woppmann et al., 1994; Nielsen et al., 1996).

The venoms of Conus Victoriae and Conus regis, respectively, contain $\alpha$-conotoxins Vc1.1 and Rg1A. These peptides were classified as $\alpha$-conotoxins in line with their action on nicotinic acetylcholine receptors (Clark et al., 2006; Nevin et al., 2007). Subsequently, potent inhibition by these toxins of Cav2.2 calcium channels was reported. However, both Vc1.1 and Rg1A do not act directly on the channel, but instead by activating $\mathrm{GABA}_{\mathrm{B}}$ receptors (Callaghan et al., 2008; Callaghan and Adams, 2010; Cuny et al., 2012; Huynh et al., 2015). This is thought to occur by interference with the receptor dimer ectodomain interface (Adams and Berecki, 2013), which then triggers inhibition of Cav2.2 channels via a $G$ protein pathway. By doing so, the Vc1.1 peptide produces analgesia in rodent models of neuropathic and gastrointestinal pain, and reduces the excitability of human dorsal root ganglion neurons (Klimis et al., 2011; Castro et al., 2016). Vc1.1 is being explored as a possible pain therapeutic for humans, and this has been facilitated through the generation of a cyclized version of the peptide that remarkably allows oral delivery of Vc1.1 (Carstens et al., 2011).

While the majority of $\omega$-conotoxins appear to target Cav2.2 and Cav2.1 calcium channels, there are some examples of L-type calcium channel blocking $\omega$-conotoxins. For example, $\omega$-conotoxin TxVII from Conus textile blocks L-type calcium channels from a freshwater pond snail, Lymnaea stagnalis (Fainzilber et al., 1996). Glacontryphan-M, an unusual peptide isolated from the venom of Conus marmoreus contains $\gamma$-carboxyglutamyl (Gla) residues in positions 2 and 4 that bestow calcium binding ability onto this toxin. It has been shown to block L-type currents in mouse pancreatic beta cells (Hansson et al., 2004). Block, however, was found to be incomplete with $\sim 35 \%$ inhibition at saturating concentrations. Substitution of the Gla residues with glutamate abolished block, as did removal of extracellular calcium.

\section{3. $\omega$-Agatoxins}

The venom of the American funnel-web spider Agenelopsis aperta contains a number of different neurotoxins, including the calcium channel blocking $\omega$ - agatoxins (Adams et al., 1993. Olivera et al., 1994). Among these, $\omega$-agatoxin IVA has been used as an experimental tool to identify and distinguish native P- and Q-type currents (Adams et al., 1993; Llinas et al., 1986; Turner et al., 1992), with P-type currents showing an approximately ten-fold greater sensitivity to this toxin. Both P-type and Q-type currents are supported by different variants of Cav2.1 channels (i.e., different splice isoforms), and differential assembly with different types of ancillary Cav $\beta$ subunits (Bourinet et al., 1999; Mermelstein et al., 1999), with alternate splicing of an asparagine-proline motif in the domain IV S3-S4 linker greatly affecting blocking affinity (Bourinet et al., 1999). This region is implicated further in toxin block by a study that examined the role of a specific glutamate residue that appears to be critical for toxin block (Winterfield and Swartz, 2000). $\omega$-agatoxin IVA is somewhat larger than the family of $\omega$ conotoxins (i.e., 48 amino acids), but also has constrained backbone structure through formation of as many as four disulfide bonds (Olivera et al., 1994).

Unlike the $\omega$-conotoxins, $\omega$-agatoxin IVA does not cause pore block, but instead acts as a gating inhibitor (Fig. 1). Binding of the toxin antagonizes the activation of the channel by preventing the movement of the voltage sensor domains (Mintz et al., 1992; McDonough et al., 1997a; Bourinet et al., 1999), which fits the notion that toxin binding occurs at a region adjacent to the voltage sensor in domain IV. This inhibition can be overcome by application of strong depolarizing voltage pulses (Mintz et al., 1992). The voltage-induced reversibility of blocking action is also reflected in a massive (i.e., many tens of millivolts) shift in the apparent halfactivation potential of the channel that is and likely due to dislodging of the toxin from its binding site by virtue of outward voltage sensor movement (Mintz et al., 1992). Although $\omega$-agatoxin IVA is selective for Cav2.1channels, higher concentrations of this toxin also have the propensity to affect other members of the Cav2 channel family, including Cav2.2 (Sidach and Mintz, 2000) and Cav2.3 (Williams et al., 1994).

A much larger member of the $\omega$-agatoxin family is $\omega$-agatoxin IIIA (Venema et al., 1992; Olivera et al., 1994). It is nearly double in size compared to IVA (78 amino acid residues) and contains as many as 12 cysteine residues that are capable of six disulfide bonds (Olivera et al., 1994). This toxin has poor selectivity among the family of high-voltage activated channels, blocking L-type, P/Qtype and N-type channels, whereas T-type calcium channels appear to be spared (Mintz et al., 1991; Mintz, 1994). This toxin acts as a pore blocker, however, a residual current remains even at saturating concentrations. In Cav2.2 channels, this residual current is insensitive to $\omega$-conotoxin GVIA, indicating that $\omega$-agatoxin IIIA may act via incomplete pore occlusion (Mintz, 1994). In contrast, in P-type channels, $\omega$-agatoxin IVA blocks this residual current, consistent with the idea that $\omega$-agatoxin IVA does not require access to the pore of the channel (Mintz, 1994).

The American funnel web spider also produces two other $\omega$ agatoxins, namely $\omega$-agatoxin IA and IIA. The former appears to be specific for insect calcium channels, whereas the latter blocks both mammalian and invertebrate channels (Olivera et al., 1994). The two toxins differ in structure, with $\omega$-agatoxin IA being a heterodimer with five disulfide bonds (Santos et al., 1992), and $\omega$-agatoxin IIA displaying only three disulfide bonds.

\section{Other toxins from spiders and scorpions}

The venom of the tarantula Grammostola spatulata contains a calcium channel blocking peptide termed $\omega$-grammotoxin SIA. This toxin acts on Cav2.1, Cav2.2 and Cav2.3 channels with micromolar affinity (Lampe et al., 1993; Piser et al., 1994, 1995; McDonough et al., 1997b; Turner et al., 1995). $\omega$-grammotoxin SIA is a gating modifier whose action is reminiscent of that of $\omega$-agatoxin IVA (McDonough et al., 1997a), such that it produces a massive shift in the half-activation potential of the channel. Interestingly, the effects of $\omega$-grammotoxin SIA and $\omega$-agatoxin IVA on Cav2.2 channels are additive, such that the apparent half activation voltage of the channels is shifted by as much as $+150 \mathrm{mV}$ when both toxins are present (McDonough et al., 1997b). This finding implies that the two toxins, although both acting by preventing voltage-sensor movement, target distinct sites or domains of the Cav2.2 subunit. Binding studies reveal that $\omega$-conotoxin GVIA cannot displace $\omega$ grammotoxin SIA from its binding site (Lampe et al., 1993), consistent with the notion that the latter is not a pore blocker.

Huwenotoxin-1 is a 33 amino acid peptide isolated from the spider Selenocosmia huwena. It has been shown to bock N-type currents in NG108-15 cells with an affinity of approximately $100 \mathrm{nM}$ (Peng et al., 2001). L-type calcium channels were also shown to be targeted by this peptide, but with much lower affinity. Low-voltage activated channels were not affected (Peng et al., 2001). Based on its folding pattern, Huwenotoxin-1 likely acts though a pore blocking mechanism similar to that of $\omega$-conotoxin MVIIA.

Venom from the tarantula Hysterocrates gigas contains a calcium channel blocking peptide termed SNX-482 which is a potent inhibitor of Cav2.3 calcium channels (Newcomb et al., 1998). Like $\omega$ - 
A

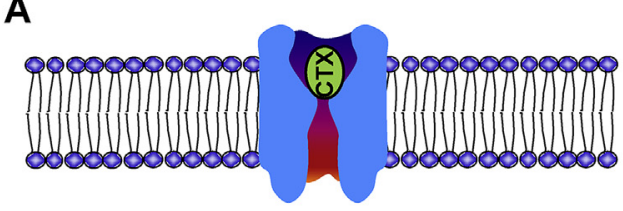

B

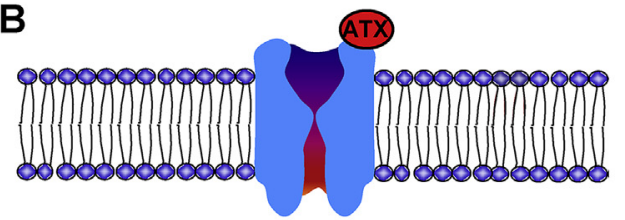

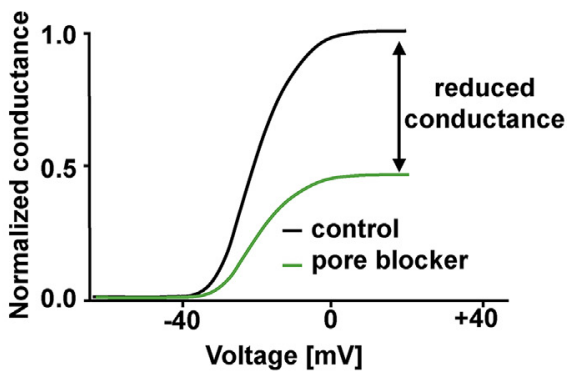

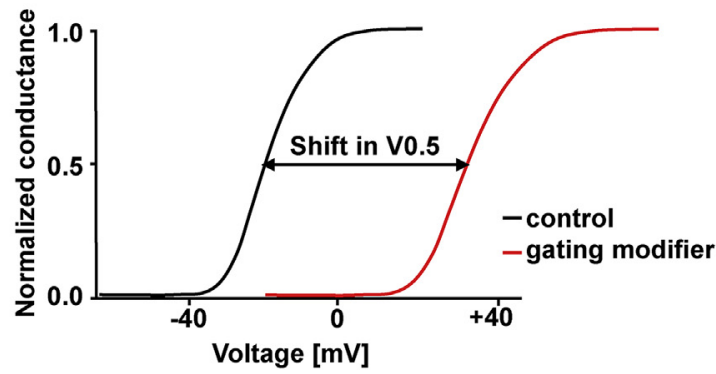

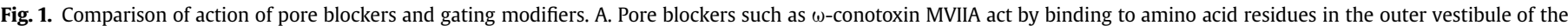

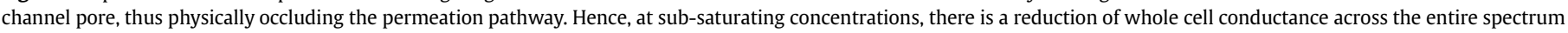

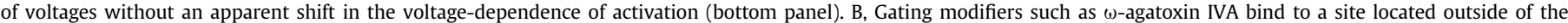

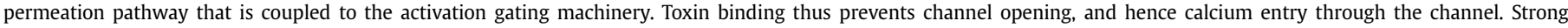

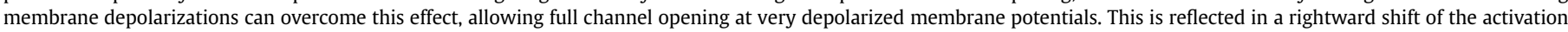
curve of the channel (bottom panel).

grammotoxin SIA and $\omega$-agatoxin IVA, this toxin triggers a shift in half activation potential of Cav2.3 channels by approximately $70 \mathrm{mV}$, indicating that it too is an activation gating modifier. This peptide also blocks Cav1.2 calcium channels, albeit incompletely (Bourinet et al., 2001). Although its precise site of action on Cav2.3 channels is unknown, block appears to involve domains III and IV of the channel as revealed by chimeras between Cav2.3 and Cav1.2. These findings indicate that despite their high affinity for calcium channels, peptides trapping voltage-sensing domains have promiscuous effects on distinct channels. This has been well documented for voltage-gated sodium channels (Bosmans and Swartz, 2010). Along these lines, SNX482 was recently shown to potently affect Kv4.2 and 4.3 potassium channels, suggesting that caution is warranted in the interpretation of neurophysiological data obtained with this peptide (Kimm and Ben, 2014). Nonetheless, SNX482 was demonstrated to have interesting effects on the descending pathways controlling opiate analgesia and on reducing morphine tolerance to pain, an effect that is mirrored in the Cav2.3 KO mice (Yokoyama et al., 2004).

SNX-325 is a 31 amino acid long peptide found in the venom of the spider Segestria florentina that contains 6 cysteine residues (Newcomb et al., 1995). It preferentially blocks Cav2.2 calcium channels, but can target other members of the high-voltage activated calcium channel family at higher concentrations. Since it is able to displace $\omega$-conotoxin MVIIA from its binding site (Newcomb et al., 1995) this toxin likely acts as a pore blocker.

The venom of the scorpion Parabuthus transvaalicus contains kurtoxin, a 63 amino acid peptide that was the first published example of a toxin acting on a member of the T-type calcium channel family (Chuang et al., 1998). However, subsequent studies have revealed that this peptide also targets members of the Cav1 and Cav2 channel families (Sidach and Mintz, 2002), in addition to voltage-gated sodium channels (Zhu et al., 2009). At least for Cav3 channels, kurtoxin acts as a gating modifier (Sidach and Mintz, 2002). The solution structure of kurtoxin reveals striking similarities to $\alpha$-scorpion toxins, but somewhat different surface properties that may explain why this toxin acts on Cav3 channels in addition to sodium channels (Lee et al., 2012).
Finally, protoxins I and II, found in the venom of the Tarantula Thrixoppelma pruriens, are potent sodium channel blockers (Middleton et al., 2002; Schmalhofer et al., 2008; Xiao et al., 2010), however, they have also been shown to potently block Cav3 calcium channels (Edgerton et al., 2010; Bladen et al., 2014). Protoxin I preferentially blocks Cav3.1 over Cav3.3 channels with about one order of magnitude higher affinity (Ohkubo et al., 2010; Bladen et al., 2014). This toxin appears to interact with residues in the domain IV region with some contribution from sites located in domain II of the Cav3.1 channels. In contrast, Cav3.2 channels are blocked with about 100-fold lower affinity. There appears to be some conservation in the binding sites of this toxin on Cav3 and Nav channels (Bladen et al., 2014). In contrast, protoxin II acts preferentially on Cav3.2 calcium channels and causes a curious shift in the half-inactivation potential of the channel (Bladen et al., 2014) that remains to be further explored. Recent structure function experiments in which the voltage sensing domains of Cav3.1 channels were transferred individually onto a Kv2.1 backbone have revealed that protoxin II may preferentially target the voltage sensor in domain III of Cav3 channels (Salari et al., 2016).

Additional toxins have been isolated from the Parabuthus transvaalicus scorpion (i.e., KLI and KLII) and the tarantula Theraphosidae (PsPTx3). The former two peptides block T-type channels and sodium channels (Olamendi-Portugal et al., 2002), whereas the latter preferentially targets T-type calcium channels, with some selectivity for Cav3.2 (E. Bourinet, unpublished observations, patent WO 2010081971 A1).

In summary, a number of calcium channel blocking peptides from various arachnids have been shown to block voltage-gated calcium channels. Many of these act as gating modifiers, however, the evolutionary significance of gating block as opposed to pore occlusion in peptide toxins from spiders versus cone snails remains to be determined.

\section{Calcium channel blocking toxins from snakes}

Black mamba (Dendroaspis polylepis) venom contains calciseptine, a 60 amino acid peptide (de Weille et al., 1991). This 
peptide has been shown to selectively block L-type calcium channels from brain and heart (de Weille et al., 1991), and was subsequently shown to compete with dihydropyridine binding to synaptosomes (Yasuda et al., 1993). Interestingly, this peptide appears to have an agonist function on Cav1.1 channels in skeletal muscle (García et al., 2001). FS2 is a related 60 amino acid peptide, also from black mamba venom, that differs from calciseptine in three amino acids. Like calciseptine, it potently blocks L-type calcium channels in smooth muscle (Yasuda et al., 1994).

Calcicludine is a 60 amino acid peptide isolated from the venom of the green mamba Dendroaspis angusticeps. It has been shown to block high-voltage activated calcium channels in cerebellar granule cells with high affinity (Schweitz et al., 1994), with L-type channels being most effectively inhibited. The effects of this toxin were also studied on heterologously expressed channels (Stotz et al., 2000), revealing several interesting features. First, block of Cav1.2, Cav2.1, Cav2.2 and Cav2.3 channels was found to be irreversible and incomplete at saturating concentrations, with Cav1.2 channels exhibiting the greatest degree of inhibition. Second, for Cav2 channels, the toxin induced a small hyperpolarizing shift in halfactivation potential, leading to a current enhancement at negative membrane potentials. Finally, experiments with chimeric calcium channels revealed that multiple membrane domains are involved in toxin block. Calcicludine binding was subsequently shown to mediate allosteric coupling to the dihydropyridine binding site (Wang et al., 2007) in line with experiments involving calciseptine (Yasuda et al., 1993).

Altogether, mamba venom contains at least three related peptide toxins that remarkable all are 60 amino acids in length, and all act by inhibiting L-type channel activity.

\section{How useful are calcium channel peptide toxins as therapeutics?}

Peptide toxins isolated from predatory species such as cone snails have long been explored as possible therapeutics, and is exemplified by the fact that entire research conferences have been dedicated to this subject (for example, Venoms to Drugs). With regard to calcium channel blocking peptides, most effort has been focused on their utility as potential analgesics. This is due to the fact that these peptides, which do not normally cross the blood brain barrier and can thus typically not be administered systemically, can be delivered to key sites of action in the pain pathway intrathecally. The only clinically approved calcium channel blocking peptide so far is Prialt ( $\omega$-conotoxin MVIIA) (Staats et al., 2004). However, it can hardly be described as a blockbuster drug, and both the need for intrathecal delivery via an implanted mini pump and the limited therapeutic index is severely limiting (Ver et al., 2008). Modification of the peptide structure into cyclized versions may provide a means for oral delivery, and thus the potential for much wider application for clinical use in humans. However, although there is now proof of concept with Vc1.1, producing such orally available peptides without loss of specificity and affinity remains challenging. Nonetheless, in addition to having been established as important and selective tools for isolation of native calcium currents (Randall and Tsien, 1995), peptide toxins retain promise as possible therapeutic agents, as either drugs, or templates for small organic mimetics. The resolution of the Cav1.1 structure may help advance the discovery of such peptide mimetics.

\section{Acknowledgments}

Work in the Zamponi laboratory is supported by a Foundation grant from the Canadian Institutes of Health Research, and a Canada Research Chairs award. The Bourinet laboratory is supported by grants from the Fondation pour la Recherche Médicale and the Agence Nationale de la Recherche.

\section{References}

Adams, M.E., Myers, R.A., Imperial, J.S., Olivera, B.M., 1993. Toxityping rat brain calcium channels with $\omega$-toxins from spider and cone snail venoms. Biochemistry 32, 12566-12570.

Adams, D.J., Smith, A.B., Schroeder, C.I., Yasuda, T., Lewis, R.J., 2003. Omega-conotoxin CVID inhibits a pharmacologically distinct voltage-sensitive calcium channel associated with transmitter release from preganglionic nerve terminals. J. Biol. Chem. 278, 4057-4062.

Adams, D.J., Berecki, G., 2013. Mechanisms of conotoxin inhibition of N-type (Ca(v) 2.2) calcium channels. Biochim. Biophys. Acta 1828, 1619-1628.

Antanassoff, P.G., Hartmannsgruber, M.W., Thrasher, J., Wermeling, D., Longton, W., Gaeta, R., Singh, T., Mayo, M., McGuire, D., Luther, R.R., 2000. Ziconotide, a new N-Type calcium channel blocker, administered intrathecally for acute postoperative pain. Reg. Anesth. Pain Med. 25, 274-278.

Berecki, G., Motin, L., Haythornthwaite, A., Vink, S., Bansal, P., Drinkwater, R., Wang, C.I., Moretta, M., Lewis, R.J., Alewood, P.F., Christie, M.J., Adams, D.J., 2010. Analgesic (omega)-conotoxins CVIE and CVIF selectively and voltagedependently block recombinant and native N-type calcium channels. Mol. Pharmacol. 77, 139-148.

Bladen, C., Hamid, J., Souza, I.A., Zamponi, G.W., 2014. Block of T-type calcium channels by Protoxins I and II. Mol. Brain 2014 (7), 36.

Boland, L.M., Morrill, J.A., Bean, B.P., 1994. $\omega$-Conotoxin block of N-type calcium channels in frog and rat sympathetic neurons. J. Neurosci. 14, 5011-5027.

Bosmans, F., Swartz, K.J., 2010. Targeting voltage sensors in sodium channels with spider toxins, 31, 175-182.

Bourinet, E., Soong, T.W., Sutton, K., Slaymaker, S., Mathews, E., Monteil, A. Zamponi, G.W., Nargeot, J., Snutch, T.P., 1999. Splicing of $\alpha 1 \mathrm{~A}$ subunit gene generates phenotypic variants of P- and Q-type calcium channels. Nat. Neurosci. 2, 407-415.

Bourinet, E., Stotz, S.C., Spaetgens, R.L., Dayanithi, G., Lemos, J., Nargeot, J., Zamponi, G.W., 2001. Interaction of SNX482 with domains III and IV inhibits activation gating of $\alpha 1 \mathrm{E}$ (Cav2.3) calcium channels. Biophys. J. 81, 79-88.

Bourinet, E., Altier, C., Hildebrand, M., Trang, T., Salter, M.W., Zamponi, G.W., 2014. Calcium permeable ion channels in pain signaling. Physiol. Rev, 94, 81-140.

Callaghan, B., Haythornthwaite, A., Berecki, G., Clark, R.J., Craik, D.J., Adams, D.J., 2008. Analgesic alpha-conotoxins Vc1.1 and Rg1A inhibit N-type calcium channels in rat sensory neurons via GABAB receptor activation. J. Neurosci. 28 , 10943-10951.

Callaghan, B., Adams, D.J., 2010. Analgesic alpha-conotoxins Vc1.1 and RgIA inhibit $\mathrm{N}$-type calcium channels in sensory neurons of alpha9 nicotinic receptor knockout mice. Channels (Austin) 4, 51-54.

Carstens, B.B., Clark, R.J., Daly, N.L., Harvey, P.J., Kaas, Q., Craik, D.J., 2011. Engineering of conotoxins for the treatment of pain. Curr. Pharm. Des. 17, 4242-4253.

Castro, J., Harrington, A.M., Garcia-Caraballo, S., Maddern, J., Grundy, L., Zhang, J. Page, G., Miller, P.E., Craik, D.J., Adams, D.J., Brierley, S.M., 2016 Feb 17. $\alpha$-Conotoxin Vc1.1 inhibits human dorsal root ganglion neuroexcitability and mouse colonic nociception via GABAB receptors. Gut. http://dx.doi.org/10.1136/gutjnl2015-310971 pii: gutjnl-2015-310971 (Epub ahead of print).

Catterall, W.A., Perez-Reyes, E., Snutch, T.P., Striessnig, J., 2005. International Union of Pharmacology. XLVIII. Nomenclature and structure-function relationships of voltage-gated calcium channels. Pharmacol. Rev. 57, 411-425.

Catterall, W.A., 2010. Ion channel voltage sensors: structure, function, and pathophysiology. Neuron 67, 915-928.

Chuang, R.S., Jaffe, H., Cribbs, L., Perez-Reyes, E., Swartz, K.J., 1998. Inhibition of Ttype voltage-gated calcium channels by a new scorpion toxin. Nat. Neurosci. 1, 668-674.

Clark, R.J., Fischer, H., Nevin, S.T., Adams, D.J., Craik, D.J., 2006. The synthesis, structural characterization, and receptor specificity of the alpha-conotoxin Vc1.1. J. Biol. Chem. 281, 23254-23263.

Cuny, H., de Faoite, A., Huynh, T.G., Yasuda, T., Berecki, G., Adams, D.J., 2012. gammaAminobutyric acid type $B(G A B A B)$ receptor expression is needed for inhibition of N-type (Cav2.2) calcium channels by analgesic alpha-conotoxins. J. Biol. Chem. 287, 23948-23957.

de Weille, J.R., Schweitz, H., Maes, P., Tartar, A., Lazdunski, M., 1991. Calciseptine, a peptide isolated from black mamba venom, is a specific blocker of the L-type calcium channel. Proc. Natl. Acad. Sci. U. S. A. 88, 2437-2440.

Dolphin, A.C., 2016 Jun 8. Voltage-gated calcium channels and their auxiliary subunits: physiology and pathophysiology and pharmacology. J. Physiol. http:/ dx.doi.org/10.1113/JP272262 (Epub ahead of print).

Edgerton, G.B., Blumenthal, K.M., Hanck, D.A., 2010. Inhibition of the activation pathway of the T-type calcium channel $\mathrm{Ca}(\mathrm{V}) 3.1$ by ProTxII. Toxicon 56, 624-636.

Ellinor, P.T., Zhang, J.F., Horne, W.A., Tsien, R.W., 1994. Structural determinants of the blockade of N-type calcium channels by a peptide neurotoxin. Nature 372, $272-275$.

Fainzilber, M., Lodder, J.C., van der Schors, R.C., Li, K.W., Yu, Z., Burlingame, A.L., Geraerts, W.P., Kits, K.S., 1996. A novel hydrophobic omega-conotoxin blocks molluscan dihydropyridine-sensitive calcium channels. Biochemistry 35, $8748-8752$. 
Feng, Z.P., Hamid, J., Doering, C., Bosey, G.M., Snutch, T.P., Zamponi, G.W., 2001. Residue Gly1326 of the N-type calcium channel alpha 1B subunit controls reversibility of $\omega$-conotoxin GVIA and MVIIA block. J. Biol. Chem. 276, $15728-15735$.

Feng, Z.P., Doering, C.J., Winkfein, R.J., Beedle, A.M., Spafford, J.D., Zamponi, G.W., 2003. Determinants of inhibition of transiently expressed voltage-gated calcium channels by $\omega$-conotoxins GVIA and MVIIA. J. Biol. Chem. 278, 20171-20178.

Fox, J.A., 1995. Irreversible and reversible blockade of IMR32 calcium channel currents by synthetic MVIIA and iodinated MVIIC $\omega$-conopeptides. Pflug. Arch. 429, $873-875$.

García, M.C., Hernández-Gallegos, Z., Escamilla, J., Sánchez, J.A., 2001. Calciseptine, a Ca2 + channel blocker, has agonist actions on L-type Ca2 + currents of frog and mammalian skeletal muscle. J. Mem. Biol. 184, 121-129.

Grantham, C.J., Bowman, D., Bath, C.P., Bell, D.C., Bleakman, D., 1994. w-conotoxin MVIIC reversibly inhibits a human N-type calcium channel and calcium influx into chick synaptosomes. Neuropharmacology 33, 255-258.

Hansson, K., Ma, X., Eliasson, L., Czerwiec, E., Furie, B., Furie, B.C., Rorsman, P., Stenflo, J., 2004. The first gamma-carboxyglutamic acid-containing contryphan. A selective L-type calcium ion channel blocker isolated from the venom of Conus marmoreus. J. Biol. Chem. 279, 32453-32463.

Hillyard, D.R., Monje, V.D., Mintz, I.M., Bean, B.P., Nadasdi, L., Ramachandran, J., Miljanich, G., Azimi-Zoonooz, A., McIntosh, J.M., Cruz, L.J., Imperial, J.S., Olivera, B.M., 1992. A new Conus peptide ligand for mammalian presynaptic Ca2 + channels. Neuron 9, 69-77.

Huynh, T.G., Cuny, H., Slesinger, P.A., Adams, D.J., 2015. Novel mechanism of voltagegated N-type (Cav2.2) calcium channel inhibition revealed through $\alpha$-conotoxin Vc1.1 activation of the GABA(B) receptor. Mol. Pharmacol. 87, 240-250.

Khosravani, H., Zamponi, G.W., 2006. Voltage-gated calcium channels and the idiopathic generalized epilepsies. Physiol. Rev. 86, 941-966.

Kimm, T., Ben, B.P., 2014. Inhibition of A-type potassium current by the peptide toxin SNX-482, 34, 9182-9189.

Klimis, H., Adams, D.J., Callaghan, B., Nevin, S., Alewood, P.F., Vaughan, C.W., Mozar, C.A., Christie, M.J., 2011. A novel mechanism of inhibition of high-voltage activated calcium channels by $\alpha$-conotoxins contributes to relief of nerve injury-induced neuropathic pain. Pain 152, 259-266.

Lampe, R.A., Defeo, P.A., Davison, M.D., Young, J., Herman, J.L., Spreen, R.C., Horn, M.B., Mangano, T.J., Keith, R.A., 1993. Isolation and pharmacological characterization of $\omega$-grammotoxin SIA, a novel peptide inhibitor of neuronal voltage-sensitive calcium channel responses. Mol. Pharmacol. 44, 451-460.

Lansman, J.B., Hess, P., Tsien, R.W., 1986. Blockade of current through single calcium channels by $\mathrm{Cd} 2+, \mathrm{Mg} 2+$, and $\mathrm{Ca} 2+$. Voltage and concentration dependence of calcium entry into the pore. J. Gen. Physiol. 88, 321-347.

Lee, S., Kim, Y., Back, S.K., Choi, H.W., Lee, J.Y., Jung, H.H., Ryu, J.H., Suh, H.W., Na, H.S., Kim, H.J., Rhim, H., Kim, J.I., 2010. Analgesic effect of highly reversible omega-conotoxin FVIA on N type Ca2+ channels. Mol. Pain 6, 97.

Lee, C.W., Bae, C., Lee, J., Ryu, J.H., Kim, H.H., Kohno, T., Swartz, K.J., Kim, J.I., 2012 Mar 6. Solution structure of kurtoxin: a gating modifier selective for Cav3 voltage-gated $\mathrm{Ca}(2+)$ channels. Biochemistry 51 (9), 1862-1873. http:// dx.doi.org/10.1021/bi201633j. Epub 2012 Feb 22, PMID: 22329781.

Lewis, R.J., Dutertre, S., Vetter, I., Christie, M.J., 2012. Conus venom peptide pharmacology. Pharmacol. Rev. 64, 259-298.

Lewis, R.J., Nielsen, K.J., Craik, D.J., Loughnan, M.L., Adams, D.A., Sharpe, I.A., Luchian, T., Adams, D.J., Bond, T., Thomas, L., Jones, A., Matheson, J.L., Drinkwater, R. Andrews, P.R., Alewood, P.F., 2000. Novel $\omega$-conotoxins from Conus catus discriminate among neuronal calcium channel subtypes. J. Biol. Chem. 275, 35335-35344.

Llinas, R., Sugimori, M., Lin, J.W., Cherksey, B., 1986. Blocking and isolation of a calcium channel from neurons in mammals and cephalopods utilizing a toxin fraction (FTX) from funnel-web spider poison. Proc. Natl. Acad. Sci. U.S.A 86, 1689-1693.

McCleskey, E.W., Fox, A.P., Feldman, D.H., Cruz, L.J., Olivera, B.M., Tsien, R.W. Yoshikami, D., 1987. $\omega$-conotoxin: direct and persistent blockade of specific types of calcium channels in neurons but not muscle. Proc. Natl. Acad. Sci. U.S.A 84, 4327-4331.

McDonough, S.I., Mintz, I.M., Bean, B.P., 1997a. Alteration of P-type calcium channel gating by the spider toxin $\omega$-Aga-IVA. Biophys. J. 72, 2117-2128.

McDonough, S.I., Lampe, R.A., Keith, R.A., Bean, B.P., 1997b. Voltage-dependent inhibition of $\mathrm{N}$ - and P-type calcium channels by the peptide toxin $\omega$-grammotoxin-SIA. Mol. Pharmacol. 52, 1095-1104.

McDonough, S.I., Boland, L.M., Mintz, I.M., Bean, B.P., 2002. Interactions among toxins that inhibit N-type and P-type calcium channels. J. Gen. Physiol. 119, $313-328$.

Mermelstein, P.G., Foehring, R.C., Tkatch, T., Song, W.J., Baranauskas, G., Surmeier, D.J., 1999. Properties of Q-type calcium channels in neostriatal and cortical neurons are correlated with beta subunit expression. J. Neurosci. 19, $7268-7277$.

Middleton, R.E., Warren, V.A., Kraus, R.L., Hwang, J.C., Liu, C.J., Dai, G., Brochu, R.M., Kohler, M.G., Gao, Y.D., Garsky, V.M., Bogusky, M.J., Mehl, J.T., Cohen, C.J., Smith, M.M., 2002. Two tarantula peptides inhibit activation of multiple sodium channels. Biochemistry 41, 14734-14747.

Miljanich, G.P., 2004. Ziconotide: neuronal calcium channel blocker for treating severe chronic pain. Curr. Med. Chem. 11, 3029-3040.

Mintz, I.M., Venema, V.J., Adams, M.E., Bean, B.P., 1991. Inhibition of N- and L-type $\mathrm{Ca} 2+$ channels by the spider venom toxin $\omega$-Aga-IIIA. Proc. Natl. Acad. Sci. U.S.A
$88,6628-6631$

Mintz, I.M., Venema, V.J., Swiderek, K.M., Lee, T.D., Bean, B.P., Adams, M.E., 1992. Ptype calcium channels blocked by the spider toxin $\omega$-Aga-IVA. Nature 355, 827-829.

Mintz, I.M., 1994. Block of Ca channels in rat central neurons by the spider toxin $\omega-$ Aga-IIIA. J. Neurosci. 14, 2844-2853.

Monje, V.D., Haack, J.A., Naisbitt, S.R., Miljanich, G., Ramachandran, J., Nasdasdi, L., Olivera, B.M., Hillyard, D.R., Gray, W.R., 1993. A new Conus peptide ligand for Ca channel subtypes. Neuropharmacology 32, 1141-1149.

Motin, L., Yasuda, T., Schroeder, C.I., Lewis, R.J., Adams, D.J., 2007. Omega-conotoxin CVIB differentially inhibits native and recombinant $\mathrm{N}$ - and $\mathrm{P} / \mathrm{Q}$-type calcium channels. Eur. J. Neurosci. 25, 435-444.

Mould, J., Yasuda, T., Schroeder, C.I., Beedle, A.M., Doering, C.J., Zamponi, G.W., Adams, D.J., Lewis, R.J., 2004. The a $2 \delta$ auxiliary subunit reduces affinity of $\omega$ conotoxins for recombinant N-type calcium channels. J. Biol. Chem. 279 34705-34714.

Nevin, S.T., Clark, R.J., Klimis, H., Christie, M.J., Craik, D.J., Adams, D.J., 2007. Are alpha9alpha10 nicotinic acetylcholine receptors a pain target for alpha-conotoxins? Mol. Pharmacol. 72, 1406-1410.

Newcomb, R., Szoke, B., Palma, A., Wang, G., Xh, Chen, Hopkins, W., Cong, R. Miller, J., Urge, L., Tarczy-Hornoch, K., Loo, J.A., Dooley, D.J., Nadasdi, L., Tsien, R.W., Lemos, J., Miljanich, G., 1998. Selective peptide antagonist of the class E calcium channel from the venom of the tarantula Hysterocrates gigas. Biochemistry 37, 15353-15362.

Newcomb, R., Palma, A., Fox, J., Gaur, S., Lau, K., Chung, D., Cong, R., Bell, J.R. Horne, B., Nadasdi, L., Ramachandran, J., 1995. SNX-325, a novel calcium antagonist from the spider Segestria florentina. Biochemistry 34, 8341-8347.

Nielsen, K.J., Thomas, L., Lewis, R.J., Alewood, P.F., Craik, D.J., 1996. A consensus structure for $\omega$-conotoxins with different selectivities for voltage-sensitive calcium channel subtypes: comparison of MVIIA, SVIB and SNX-202. J. Mol. Biol. 263, 297-310.

Ohkubo, T., Yamazaki, J., Kitamura, K., 2010. Tarantula toxin ProTx-I differentiates between human T-type voltage-gated Ca2+ channels Cav3.1 and Cav3.2. J. Pharmacol. Sci. 112, 452-458.

Olamendi-Portugal, T., Garcia, B.I., Lopez-Gonzalez, I., Van Der Walt, J., Dyason, K., Ulens, C., Tytgat, J., Felix, R., Darszon A,Possani, L.D., 2002. Two new scorpion toxins that target voltage-gated $\mathrm{Ca} 2+$ and $\mathrm{Na}+$ channels. Biochem. Biophys. Res. Commun. 299, 562-568.

Olivera, B.M., Gray, W.R., Zeikus, R., McIntosh, J.M., Varga, J., Rivier, J., de Santos, V. Cruz, L.J., 1985. Peptide neurotoxins from fish-hunting cone snails. Science 230, $1338-1343$.

Olivera, B.M., Cruz, L.J., de Santos, V., LeCheminant, G.W., Griffin, D., Zeikus, R., McIntosh, J.M., Galyean, R., Varga, J., Gray, W.R., Rivier, J., 1986. Neuronal calcium channel antagonists. Discrimination between calcium channel subtypes using $\omega$-conotoxin from Conus magus venom. Biochemistry 26, 2086-2090.

Olivera, B.M., Rivier, J., Scott, J.K., Hillyard, D.R., Cruz, L.J., 1991. Conotoxins. J. Biol. Chem. 266, 22067-22070.

Olivera, B.M., Miljanich, G.P., Ramachandran, J., Adams, M.E., 1994. Calcium channe diversity and neurotransmitter release: the $\omega$-conotoxins and $\omega$-agatoxins Annu. Rev. Biochem. 63, 823-867.

Peng, K., Chen, X.D., Liang, S.P., 2001. The effect of Huwentoxin-I on Ca(2+) channels in differentiated NG108-15 cells, a patch-clamp study. Toxicon 39, 491-498.

Penn, R.D., Paice, J.A., 2000. Adverse effects associated with the intrathecal administration of ziconotide. Pain 85, 291-296.

Piser, T.M., Lampe, R.A., Keith, R.A., Thayer, S.A., 1994. $\omega$-Grammotoxin blocks action-potential-induced $\mathrm{Ca} 2+$ influx and whole-cell $\mathrm{Ca} 2+$ current in rat dorsal-root ganglion neurons. Pflug. Arch. 426, 214-220.

Piser, T.M., Lampe, R.A., Keith, R.A., Thayer, S.A., 1995. multiple, voltage-gated, Ca2 + channel subtypes in cultured rat hippocampal neurons. Mol. Pharmacol. 48, 131-139.

Pragnell, M., De Waard, M., Mori, Y., Tanabe, T., Snutch, T.P., Campbell, K.P., 1994. Calcium channel beta-subunit binds to a conserved motif in the I-II cytoplasmic linker of the alpha1-subunit. Nature 368, 67-70.

Ramilo, C.A., Zafaralla, G.C., Nadasdi, L., Hammerland, L.G., Yoshikami, D., Gray, W.R. Kristipati, R., Ramachandran, J., Miljanich, G., Olivera, B.M., Cruz, L.J., 1992. Novel $\alpha$ - and $\omega$-conotoxins from Conus striatus venom. Biochemistry 31, 9919-9926.

Randall, A., Tsien, R.W., 1995. Pharmacological dissection of multiple types of Ca2+ channel currents in rat cerebellar granule neurons. J. Neurosci. 15, 2995-3012.

Sadeghi, M., Murali, S.S., Lewis, R.J., Alewood, P.F., Mohammadi, S., Christie, M.J. 2013. Novel $\omega$-conotoxins from C. catus reverse signs of mouse inflammatory pain after systemic administration. Mol. Pain 9, 51.

Salari, A., Vega, B.S., Milescu, L.S., Milescu, M., 2016. Molecular interactions between Tarantula toxins and low-voltage-activated calcium channels. Sci. Rep. 6, 23894

Santos, A.D., Imperial, J.S., Chaudhary, T., Beavis, R.C., Chait, B.T., Hunsperger, J.P. Olivera, B.M., Adams, M.E., Hillyard, D.R., 1992. Heterodimeric structure of the spider toxin $\omega$-agatoxin IA revealed by precursor analysis and mass spectrometry. J. Biol. Chem. 267, 20701-20705.

Schmalhofer, W.A., Calhoun, J., Burrows, R., Bailey, T., Kohler, M.G., Weinglass, A.B. Kaczorowski, G.J., Garcia, M.L., Koltzenburg, M., Priest, B.T., 2008. ProTx-II, a selective inhibitor of NaV1.7 sodium channels, blocks action potential propagation in nociceptors. Mol. Pharmacol. 74, 1476-1484.

Schroeder, C.I., Doering, C.J., Zamponi, G.W., Lewis, R.J., 2006. N-type calcium channel blockers: novel therapeutics for the treatment of pain. Med. Chem. 2 535-543.

Schweitz, H., Heurteaux, C., Bois, P., Moinier, D., Romey, G., Lazdunski, M., 1994 
Calcicludine, a venom peptide of the Kunitz-type protease inhibitor family, is a potent blocker of high-threshold $\mathrm{Ca} 2+$ channels with a high affinity for L-type channels in cerebellar granule neurons. Proc. Natl. Acad. Sci. U. S. A. 91, $878-882$.

Scott, D.A., Wright, C.E., Angus, J.A., 2002. Actions of intrathecal $\omega$-conotoxins CVID, GVIA, MVIIA, and morphine in acute and neuropathic pain in the rat. Eur. J. Pharmacol. 451, 279-286.

Sidach, S.S., Mintz, I.M., 2000. Low-affinity blockade of neuronal N-type Ca channels by the spider toxin $\omega$-agatoxin-IVA. J. Neurosci. 20, 7174-7182.

Sidach, S.S., Mintz, I.M., 2002. Kurtoxin, a gating modifier of neuronal high- and low-threshold Ca channels. J. Neurosci. 22, 2023-2034.

Simms, B.A., Zamponi, G.W., 2014. Neuronal voltage gated calcium channels: structure, function and dysfunction. Neuron 82, 24-45.

Staats, P.S., Yearwood, T., Charapata, S.G., Presley, R.W., Wallace, M.S., ByasSmith, M., Fisher, R., Bryce, D.A., Mangieri, E.A., Luther, R.R., Mayo, M., McGuire, D., Ellis, D., 2004. Intrathecal ziconotide in the treatment of refractory pain in patients with cancer or AIDS: a randomized controlled trial. JAMA 291, 63-70.

Stocker, J.W., Nadasdi, L., Aldrich, R.W., Tsien, R.W., 1997. Preferential interaction of omega-conotoxins with inactivated N-Type Ca2+ channels. J. Neurosci. 17, 3002-3013.

Stotz, S.C., Spaetgens, R.L., Zamponi, G.W., 2000. Block of voltage-dependent calcium channel by the green mamba toxin calcicludine. J. Membr. Biol. 174, 157-165.

Thompson, J.C., Dunbar, E., Laye, R.R., 2006. Treatment challenges and complications with Ziconotide monotherapy in established pump patients. Pain Physician 9, 147-152.

Turner, T.J., Adams, M.E., Dunlap, K., 1992. Calcium channels coupled to glutamate release identified by $\omega$-Aga-IVA. Science 258, 310-313.

Turner, T.J., Lampe, R.A., Dunlap, K., 1995. Characterization of presynaptic calcium channels with $\omega$-conotoxin MVIIC and $\omega$-grammotoxin SIA: role for a resistant calcium channel type in neurosecretion. Mol. Pharmacol. 47, 348-353.

Venema, V.J., Swiderek, K.M., Lee, T.D., Hathaway, G.M., Adams, M.E., 1992. Antagonism of synaptosomal calcium channels by subtypes of omega-agatoxins. J. Biol. Chem. 267, 2610-2615.

Ver, D.A., Collins, R., Rauck, R.L., Nitescu, P., 2008. An open-label, multicenter study of the safety and efficacy of intrathecal ziconotide for severe chronic pain when delivered via an external pump. Neuromodulation 11, 103-111.

Wallace, M.S., Charapata, S.G., Fisher, R., Byas-Smith, M., Staats, P.S., Mayo, M., McGuire, D., Ellis, D., 2006. Intrathecal Ziconotide in the treatment of chronic nonmalignant pain: a randomized, double-blind, placebo-controlled clinica trial. Neuromodulation 9, 75-86.

Wang, X., Du, L., Peterson, B.Z., 2007. Calcicludine binding to the outer pore of Ltype calcium channels is allosterically coupled to dihydropyridine binding. Biochemistry 46, 7590-7598.
Wang, F., Yan, Z., Liu, Z., Wang, S., Wu, Q., Yu, S., Ding, J., Dai, Q., 2016. Molecular basis of toxicity of N-type calcium channel inhibitor MVIIA. Neuropharmacology 101, 137-145.

Waxman, S.G., Zamponi, G.W., 2014. Regulating excitability of peripheral afferents: emerging ion channel targets. Nat. Neurosci. 17, 153-163.

Winterfield, J.R., Swartz, K.J., 2000. A hot spot for the interaction of gating modifier toxins with voltage-dependent ion channels. J. Gen. Physiol. 116, 637-644.

Woppmann, A., Ramachandran, J., Miljanich, G.P., 1994. Calcium channel subtypes in rat brain: biochemical characterization of the high-affinity receptors for $\omega$ conopeptides SNX-230 (synthetic MVIIC), SNX-183 (SVIB), and SNX-111 (MVIIA). Mol. Cell Neurosci. 5, 350-357.

Williams, M.E., Marubio, L.M., Deal, C.R., Hans, M., Brust, P.F., Philipson, L.H., Miller, R.J., Johnson, E.C., Harpold, M.M., Ellis, S.B., 1994. Structure and functional characterization of neuronal $\alpha 1 \mathrm{E}$ calcium channel subtypes. J. Biol. Chem. 269, 22347-22357.

Wu, J., Yan, Z., Li, Z., Yan, C., Lu, S., Dong, M., Yan, N., 2015. Structure of the voltagegated calcium channel Cav1.1 complex. Science 350, 2395.

Wu, J., Yan, Z., Li, Z., Qian, X., Lu, S., Dong, M., Zhou, Q., Yan, N., 2016. Structure of the voltage-gated calcium channel Cav1.1 at 3.6 A resolution. Nature, 10.1038.

Xiao, W.H., Bennett, G.J., 1995. Synthetic omega-conopeptides applied to the site of nerve injury suppress neuropathic pains in rats. J. Pharmacol. Exp. Ther. 274, $666-672$.

Xiao, Y., Blumenthal, K., Jackson 2nd, J.O., Liang, S., Cummins, T.R., 2010. The tarantula toxins ProTx-II and huwentoxin-IV differentially interact with human Nav1.7 voltage sensors to inhibit channel activation and inactivation. Mol. Pharmacol. 78, 1124-1134.

Yasuda, O., Morimoto, S., Chen, Y., Jiang, B., Kimura, T., Sakakibara, S., Koh, E. Fukuo, K., Kitano, S., Ogihara, T., 1993. Calciseptine binding to a 1,4-dihydropyridine recognition site of the L-type calcium channel of rat synaptosomal membranes. Biochem. Biophys. Res. Commun. 194, 587-594.

Yasuda, O., Morimoto, S., Chen, Y., Jiang, B., Kimura, T., Sakakibara, S., Koh, E. Fukuo, K., Kitano, S., Ogihara, T., 1994. FS2. a mamba venom toxin, is a specific blocker of the L-type calcium channels. Artery 21, 287-302.

Yokoyama, K., Kurihara, T., Saegusa, H., Zong, S., Makita, K., Tanabe, T. 2004 Blocking the R-type (Cav2.3) Ca2 + channel enhanced morphine analgesia and reduced morphine tolerance. Eur. J. Neurosci. 20, 3516-3519.

Zamponi, G.W., Striessnig, J., Koschak, A., Dolphin, A.C., 2015. The physiology, pharmacology and pathology of voltage-gated calcium channels and their therapeutic potential. Pharmacol. Rev. 67, 821-870.

Zamponi, G.W., 2016. Targeting voltage-gated calcium channels in neurological and psychiatric diseases. Nat. Rev. Drug Disc. 15, 19-34.

Zhu, H.L., Wassall, R.D., Cunnane, T.C., Teramoto, N., 2009. Actions of kurtoxin on tetrodotoxin-sensitive voltage-gated $\mathrm{Na}+$ currents, NaV1.6, in murine vas deferens myocytes. Naunyn Schmiedeb. Arch. Pharmacol. 379, 453-460. 